\title{
Maria Finogenow
}

Instytut Psychologii Uniwersytetu Łódzkiego

\section{Strategie radzenia sobie ze stresem a subiektywna ocena stanu zdrowia osób w wieku emerytalnym}

\section{Wprowadzenie}

Od wieków przedstawiciele różnych dziedzin nauki, medycyny, alchemii, filozofii, religii, poszukiwali przyczyn starzenia się człowieka. Próbowano również odnaleźć skuteczny sposób na wydłużenie życia ludzkiego. Poprawa warunków materialnych oraz postęp medycyny pozwoliły na częściowe zrealizowanie odwiecznych marzeń ludzkości o długim życiu. Przeciętny czas trwania życia ludzkiego znacznie się wydłużył, obserwuje się również wzrost proporcji osób starzejących się i starych w ogólnej populacji ludzi wielu krajów (por. F in ogenow, 2011a; Frącki ew ic z, 2002; S traś-R o m an ow s ka, 2000; Trafiałek, 2003). W obliczu tych zmian szczególnego znaczenia nabierają badania i poszukiwania $\mathrm{w}$ zakresie szeroko rozumianej jakości życia osób starszych.

Wielu autorów (np. Bryniewi c z, 2007; S e mków, 2007) wskazuje na potrzebę badań w tym obszarze w Polsce, co wynika z przemian, jakie wystąpiły w społeczeństwie polskim po transformacji systemowej. Zaistniałe po tym okresie zmiany utrudniają integrację i utrwalenie pozycji społecznej osób starszych. Osoby starsze mają coraz więcej trudności w dostosowaniu się do nowej struktury społecznej, zmieniającego się systemu wartości - opartego na indywidualizmie, kulcie pieniądza i konkurencji - oraz wprowadzanych licznych nowych technologii (Moj s i in., 2007).

Przekroczenie progu starości niejednokrotnie utożsamiane jest $\mathrm{z}$ osiagnięciem przez człowieka wieku emerytalnego i zaprzestaniem aktywności zawodowej. Przejście na emeryturę traktowane jest jako jedno $\mathrm{z}$ najważniejszych wydarzeń krytycznych $\mathrm{w}$ tym okresie życia (por. Pinquart, Schindler, 2007; S tráś-R o ma nowska, 2000), które może wpływać na różne aspekty szeroko rozumianej jakości życia (P a s i k, 2007b).

Dla wielu osób wiąże się ono z utratą dotychczasowego statusu zawodowego i materialnego, a także obniżeniem poczucia znaczenia, prestiżu oraz wzrostem poczucia bezużyteczności. Zaliczenie do grona osób w wieku „nieproduktywnym” bywa dla niektórych równoznaczne z zaliczeniem do osób „niepo- 
trzebnych". Istnieje także grupa badaczy, którzy twierdzą, że zmiana ta może być odbierana pozytywnie i powodować rozwój nowych zainteresowań oraz wiązać się z wyznaczaniem sobie nowych celów (por. Wu i in., 2005). Dla części osób przejście na emeryturę jest koniecznością, podczas gdy dla innych stanowi długo wyczekiwaną chwile (F in o g e n o w, 2011b).

Jednak bez względu na to, czy przejście na emeryturę jest pozytywną czy negatywną zmianą w życiu człowieka starszego, zawsze jest to sytuacja trudna, wymagająca przystosowania do nowych warunków (Langlois, Cramer, 2005). Moment podejmowania decyzji i przechodzenia na emeryturę jest dla wielu ludzi przełomowym okresem w życiu, związanym ze zmianą pełnionej dotychczas roli, przeorganizowaniem dotychczasowego stylu życia, zmianą ilości i jakości kontaktów interpersonalnych. Wielu badaczy zajmujących się emeryturą (por. B e ehr, 1986) podkreśla także, że emerytura jest procesem rozpoczynającym się planowaniem i podejmowaniem decyzji o przejściu na emeryturę przed zakończeniem życia zawodowego i trwa jeszcze przez kilka lat po przejściu na emeryturę.

Wyniki badań nad wpływem sytuacji trudnej, jaką jest przejście na emeryturę, na stan zdrowia, wskazują, że może on pozostawać stabilny, a niekiedy nawet polepszać się w pierwszym okresie emerytury. W badaniach T. L. Galla i in. (1997) w poczattkowym okresie (od 2-4 miesięcy przed do 1 roku po wycofaniu się z aktywności zawodowej) emerytura doświadczana była pozytywnie w odniesieniu do wielu aspektów zdrowia (spadek zachorowalności, wzrost poziomu energii, wysokie poczucie subiektywnego zdrowia). Wyniki te pozostaja w zgodzie z sugerowaną przez R. C. Atchleya (1976, za: Gall i in., 1997) fazą „miesiąca miodowego" w początkowym okresie emerytury. W okresie tym emeryt ma dużo energii, czuje się zdrowy psychologicznie, uważa, że ma wpływ na swoje życie, ma satysfakcjonującą ilość pieniędzy i cieszy się z relacji z innymi. Dopiero późniejsze lata emerytury wiążą się ze spadkiem fizycznego i psychologicznego zdrowia, co może być związane z ogólnym spadkiem zdrowia u osób starszych (P a l m or e, 1986). Wyniki badań wskazują również jednoznacznie na ważną rolę stanu zdrowia $\mathrm{w}$ procesie przystosowania do emerytury. W prowadzonych badaniach wykazano, że zdrowie fizyczne jest jednym z najważniejszych predyktorów przystosowania do emerytury (np. B os sé i in., 1991; Hard y, Qu a d a g n o, 1995; S e c c o m b e, Le e, 1986).

Współczesne zainteresowanie problematyką stresu skupia się jednak nie tyle na przyczynach stresu, lecz głównie wokół sposobów radzenia sobie z nim. W licznych badaniach autorzy zwracają uwagę na rolę różnych zasobów osobistych i społecznych $\mathrm{w}$ procesie przystosowywania się do zachodzących zmian (np.: Finogenow, 2008; Pasik, 2007b; P inquart, Schindler, 2007; Swagler, J ome, 2005; W ard i in., 2004). Dzięki pewnym dyspozycjom osobowościowym, predysponującym do pozytywnej bądź negatywnej oceny własnego życia, zachodzące zmiany mogą w większym bądź mniejszym stopniu wpływać na jakość życia i poziom doświadczanego stresu w tym okresie życia. 
Skuteczne radzenie sobie jest traktowane jako ważny wyznacznik dobrego funkcjonowania psychologicznego i somatycznego (Heszen, Sęk, 2007). R. S. Lazarus i S. Folkman (1984) definiuja radzenie sobie ze stresem (coping) jako poznawcze i behawioralne starania zmierzające do sprostania specyficznym wymaganiom zewnętrznym i/lub wewnętrznym, które zostały przez jednostkę ocenione jako wymagające wielkiego wysiłku lub przekraczające jej zasoby. Funkcją radzenia sobie jest rozwiązanie problemu bądź zmiana sytuacji trudnej oraz regulacja doświadczeń emocjonalnych, celem zaś przywrócenie równowagi organizmu, uniknięcie lub zminimalizowanie niekorzystnych skutków (H e s z e n, S ę k, 2007).

Doświadczany w obliczu sytuacji trudnych stres może prowadzić do zaburzeń stanu zdrowia zarówno bezpośrednio, jak i pośrednio. Zmiany bezpośrednie wynikają $\mathrm{z}$ zachodzących $\mathrm{w}$ organizmie procesów fizjologicznych, natomiast zmiany pośrednie występują na skutek podejmowania zachowań niekorzystnych dla zdrowia. U osób, u których występują deficyty w zakresie skutecznych strategii radzenia sobie, sytuacje stresujące o dużym nasileniu, trwające dość długo, często przekraczają możliwości adaptacyjne. To z kolei sprzyja zakłóceniom $w$ funkcjonowaniu jednostki, dezorganizacji zachowania oraz zaburzeniom w zakresie stanu zdrowia (por. Kaflik-Pieróg, Z adworna-Cieślak, 2010). Zależności te potwierdzane są w licznych badaniach (np. D u d e k, 1998; Kaflik-P i eróg, 2004; O g ińs k a-B u lik, 2006).

Celem podjętych badań było:

- wykrycie związków występujących między strategiami radzenia sobie ze stresem a subiektywną oceną stanu zdrowia osób w okresie zmian emerytalnych;

- ustalenie predyktorów subiektywnej oceny stanu zdrowia osób w wieku emerytalnym spośród stosowanych strategii radzenia sobie;

- sprawdzenie, czy sytuacja zawodowa i płeć stanowią źródło zmienności wyników uzyskiwanych w zakresie subiektywnej oceny stanu zdrowia.

\section{Metoda}

Kryterium w doborze badanej grupy stanowił wiek, w którym większość osób wycofuje się z aktywności zawodowej. W badaniach uczestniczyło 240 osób w wieku 55-70 lat (średnia wieku 60,1 lat) z województwa łódzkiego, w równej liczebności kobiet i mężczyzn. Grupa była również zróżnicowana pod względem sytuacji zawodowej: połowa osób przeszła już na emeryturę, połowa wciąż kontynuowała aktywność zawodową w pełnym wymiarze godzin.

$\mathrm{W}$ badaniach zastosowano następujące techniki badawcze:

- Wielowymiarowy Inwentarz Radzenia Sobie (COPE; C. S. Carver, M. F. Scheier, J. K. Weintraub) w polskiej adaptacji Z. Juczyńskiego (J u c z y ń s k i, 
Ogińska-Bulik, 2009). Technika ta zawiera 60 stwierdzeń wchodzących w skład 15 strategii radzenia sobie ze stresem.

- Lista Objawów Somatycznych L. Cofty (za: Golińska, 2003). Lista służy do badania subiektywnej oceny stanu zdrowia. W oparciu o podaną przez badanych częstotliwość i intensywność doświadczanych dolegliwości somatycznych pozwala na określenie zakresu i nasilenia objawów somatycznych.

\section{Wyniki}

\subsection{Strategie radzenia sobie ze stresem a subiektywna ocena stanu zdrowia}

Na wstępie sprawdzono, czy strategie radzenia sobie ze stresem korelują ze wskaźnikami stanu zdrowia osób starszych. Wyniki przedstawiono w tab. 1.

Tabela 1

Współczynniki korelacji liniowej ( $r$-Pearsona) między strategiami radzenia sobie ze stresem a subiektywną oceną stanu zdrowia

\begin{tabular}{|l|c|c|}
\hline \multirow{2}{*}{\multicolumn{1}{|c|}{ Strategia radzenia sobie ze stresem }} & \multicolumn{2}{c|}{ Subiektywna ocena stanu zdrowia } \\
\cline { 2 - 3 } & $\begin{array}{c}\text { zakres objawów } \\
\text { somatycznych }\end{array}$ & $\begin{array}{c}\text { nasilenie objawów } \\
\text { somatycznych }\end{array}$ \\
\hline Aktywne radzenie sobie & $-0,10$ & $-0,11$ \\
\hline Planowanie & $-0,12$ & $-0,08$ \\
\hline Poszukiwanie instrumentalnego wsparcia & $-0,04$ & $-0,01$ \\
\hline Poszukiwanie emocjonalnego wsparcia & $-0,00$ & 0,05 \\
\hline Unikanie konkurencyjnych działań & $-0,11$ & $-0,07$ \\
\hline Zwrot ku religii & $\mathbf{0 , 2 5}$ *** & $\mathbf{0 , 2 9}$ *** \\
\hline Pozytywne przewartościowanie & $\mathbf{- 0 , 1 9 * *}$ & $-\mathbf{0 , 2 3}$ * $^{* *}$ \\
\hline Powstrzymywanie się od działania & $-0,08$ & $-0,04$ \\
\hline Akceptacja & $-0,09$ & $-0,01$ \\
\hline Koncentracja na emocjach i ich wyładowanie & 0,11 & $\mathbf{0 , 2 1}$ ** \\
\hline Zaprzeczanie & $\mathbf{0 , 2 1 * *}$ & $\mathbf{0 , 1 9 * *}$ \\
\hline Odwracanie uwagi & 0,10 & 0,11 \\
\hline Zaprzestanie działań & $\mathbf{0 , 1 8 * *}$ & $\mathbf{0 , 2 3}$ *** \\
\hline Używanie alkoholu/narkotyków & $\mathbf{0 , 1 2}$ & $\mathbf{0 , 1 5 *}$ \\
\hline Poczucie humoru & 0,04 & $-0,03$ \\
\hline
\end{tabular}

${ }^{*} p<0,05 ; * * p<0,01 ; * * * p<0,001 ;{ }^{a}$ tendencyjne $p<0,1$. 
Analiza korelacyjna wykazała istnienie istotnych pozytywnych (choć słabych) związków między zakresem i nasileniem dolegliwości somatycznych a strategiami emocjonalnymi i unikowymi (zwrot ku religii, zaprzeczanie, zaprzestanie działań, używanie alkoholu/narkotyków) oraz związek negatywny ze strategią polegającą na pozytywnym przewartościowaniu. $\mathrm{Z}$ nasileniem objawów somatycznych pozytywnie wiąże się także strategia polegająca na koncentracji na emocjach i ich wyładowaniu. Im częstsze stosowanie strategii unikowych i emocjonalnych, tym gorsze wskaźniki stanu zdrowia.

W celu przeanalizowania znaczenia stosowanych strategii radzenia sobie dla subiektywnej oceny stanu zdrowia porównano osoby deklarujące dobry stan zdrowia z osobami deklarującymi zły stan zdrowia. W tym celu, ze względu na brak norm stenowych, wyniki (obu wskaźników stanu zdrowia) zostały podzielone na trzy poziomy metodą percentyli, z których dwie skrajne grupy zostały poddane analizie. W pierwszej grupie, deklarującej dobry stan zdrowia (niski zakres i niskie nasilenie), znalazły się 63 osoby (24 kobiety i 39 mężczyzn).

Tabela 2

Strategie radzenia sobie u osób z dobrym i złym stanem zdrowia

\begin{tabular}{|c|c|c|c|c|c|c|}
\hline \multirow{3}{*}{ Strategia radzenia sobie } & \multicolumn{4}{|c|}{ Stan zdrowia } & \multirow{3}{*}{$t$} & \multirow{3}{*}{$p$} \\
\hline & \multicolumn{2}{|c|}{ dobry } & \multicolumn{2}{|c|}{ zły } & & \\
\hline & $M$ & $S D$ & $M$ & $S D$ & & \\
\hline Aktywne radzenie sobie & 11,63 & 2,76 & 11,16 & 2,27 & 1,016 & ni \\
\hline Planowanie & 11,56 & 2,83 & 11,29 & 2,91 & 0,512 & ni \\
\hline $\begin{array}{l}\text { Poszukiwanie instrumentalnego } \\
\text { wsparcia }\end{array}$ & 10,70 & 2,76 & 10,75 & 2,33 & $-0,109$ & ni \\
\hline $\begin{array}{l}\text { Poszukiwanie emocjonalnego } \\
\text { wsparcia }\end{array}$ & 10,13 & 3,26 & 10,20 & 2,453 & $-0,130$ & ni \\
\hline $\begin{array}{l}\text { Unikanie konkurencyjnych } \\
\text { działań }\end{array}$ & 11,35 & 2,280 & 10,80 & 2,00 & 1,381 & ni \\
\hline Zwrot ku religii & 8,52 & 4,10 & 10,88 & 3,39 & $-3,385$ & 0,001 \\
\hline Pozytywne przewartościowanie & 11,65 & 2,33 & 10,54 & 2,30 & 2,620 & $\mathbf{0 , 0 1}$ \\
\hline $\begin{array}{l}\text { Powstrzymywanie się od } \\
\text { działania }\end{array}$ & 10,76 & 2,01 & 10,43 & 1,83 & 0,943 & ni \\
\hline Akceptacja & 10,48 & 2,68 & 9,80 & 2,16 & 1,497 & ni \\
\hline $\begin{array}{l}\text { Koncentracja na emocjach i ich } \\
\text { wyładowanie }\end{array}$ & 10,48 & 2,74 & 11,30 & 2,07 & $-1,842$ & tend. \\
\hline Zaprzeczanie & 6,84 & 1,89 & 7,73 & 2,29 & $-2,325$ & 0,05 \\
\hline Odwracanie uwagi & 8,35 & 2,53 & 9,16 & 2,14 & $-1,878$ & tend. \\
\hline Zaprzestanie działań & 6,81 & 1,88 & 7,91 & 2,69 & $-2,608$ & $\mathbf{0 , 0 1}$ \\
\hline Używanie alkoholu/narkotyków & 4,63 & 1,83 & 5,29 & 2,46 & $-1,649$ & $\mathrm{ni}$ \\
\hline Poczucie humoru & 6,21 & 2,27 & 6,46 & 2,50 & $-0,589$ & $\mathrm{ni}$ \\
\hline
\end{tabular}

tend. $-p$ tendencyjne. 
W grupie drugiej, deklarującej zły stan zdrowia (wysoki zakres i wysokie nasilenie), znalazło się 56 osób (43 kobiety i 13 mężczyzn). W tab. 2 przedstawiono wyniki analizy porównawczej.

Wyróżnione ze względu na stan zdrowia grupy różnią się tylko niektórymi strategiami radzenia sobie ze stresem. Istotne różnice wystapiły zarówno w przypadku strategii zaliczanych do unikowych (zaprzeczanie, odwracanie uwagi, zaprzestanie działań), jak i skoncentrowanych na emocjach (zwrot ku religii, koncentracja na emocjach). Jedyna różnica wśród strategii aktywnych dotyczy pozytywnego przewartościowania. Osoby deklarujące dobry stan zdrowia, w sytuacjach stresowych rzadziej koncentrują się na emocjach i w mniejszym stopniu korzystają ze strategii unikowych. Częściej zaś potrafią odnaleźć w sytuacjach trudnych wartości korzystne dla swojego rozwoju, spostrzec je w bardziej pozytywnym świetle.

Następnym etapem było wyłonienie predyktorów subiektywnej oceny stanu zdrowia spośród wszystkich stosowanych strategii radzenia sobie ze stresem. W tym celu przeprowadzono analizę regresji wielokrotnej krokowej oddzielnie dla zakresu i nasilenia objawów somatycznych (tab. 3 i 4). Do analizy włączono tylko te strategie, których związek $\mathrm{z}$ danym aspektem miał charakter monotoniczny oraz był istotny statystycznie.

T a b e la 3

Predyktory zakresu objawów somatycznych

\begin{tabular}{|l|c|c|c|c|c|c|}
\hline \multicolumn{1}{|c|}{ Strategie radzenia sobie } & $R^{2}$ & $\begin{array}{c}\text { Skorygowane } \\
R^{2}\end{array}$ & $\begin{array}{c}\text { Zmiana } \\
R^{2}\end{array}$ & $\beta$ & $t$ & $p$ \\
\hline Zwrot ku religii & 0,064 & 0,060 & 0,064 & 0,214 & 3,464 & 0,001 \\
\hline Zaprzeczanie & 0,095 & 0,087 & 0,031 & 0,173 & 2,814 & 0,005 \\
\hline Pozytywne przewartościowanie & 0,120 & 0,109 & 0,025 & $-0,160$ & $-2,607$ & 0,010 \\
\hline
\end{tabular}

Analiza regresji dla zakresu objawów somatycznych ujawniła trzy predyktory odpowiedzialne za $11 \%$ wariancji całkowitej (tab. 3). Model okazał się dobrze dopasowany do danych $F(3,236)=10,755 ; p<0,001$. Największy udział w predykcji zakresu odczuwanych dolegliwości posiada strategia związana z poszukiwaniem w religii emocjonalnego wsparcia, drogowskazu do pozytywnej reinterpretacji sytuacji trudnej. Pozostałe strategie oznaczone jako istotne w analizie regresji (zaprzeczanie, odrzucanie faktu zaistniałej sytuacji trudnej oraz pozytywne przewartościowanie) odgrywają już mniejszą rolę.

Przeprowadzona analiza regresji dla nasilenia objawów somatycznych ujawniła cztery predyktory, wyjaśniające łącznie $16 \%$ wariancji wyników (tab. 4). Także ten model $\mathrm{w}$ istotnym stopniu wyjaśniał zmienność $\mathrm{w}$ poziomie zmiennej zależnej $F(4,235)=12,088 ; p<0,001$. Najważniejszą rolę w przewidywaniu nasilenia odczuwanych dolegliwości somatycznych odgrywa (tak jak 
Predyktory nasilenia objawów somatycznych

\begin{tabular}{|l|c|c|c|c|c|c|}
\hline \multicolumn{1}{|c|}{ Strategie radzenia sobie } & $R^{2}$ & $\begin{array}{c}\text { Skorygowane } \\
R^{2}\end{array}$ & $\begin{array}{c}\text { Zmiana } \\
R^{2}\end{array}$ & $\beta$ & $t$ & $p$ \\
\hline Zwrot ku religii & 0,086 & 0,082 & 0,086 & 0,238 & 3,924 & 0,000 \\
\hline Zaprzestanie działań & 0,128 & 0,120 & 0,042 & 0,149 & 2,405 & 0,017 \\
\hline Pozytywne przewartościowanie & 0,151 & 0,141 & 0,024 & $-0,163$ & $-2,657$ & 0,008 \\
\hline Zaprzeczanie & 0,171 & 0,157 & 0,019 & 0,142 & 2,337 & 0,020 \\
\hline
\end{tabular}

w przypadku zakresu dolegliwości somatycznych) poszukiwanie w religii źródła emocjonalnego wsparcia w sytuacjach trudnych. Istotną rolę pełni także zaprzestawanie działań, rezygnowanie z podejmowania wysiłków osiagnięcia pożądanego rezultatu. Istotne okazały się także strategie pozytywnego przewartościowania oraz zaprzeczania zaistniałej sytuacji (choć ich udział w predykcji tej zmiennej nie jest duży).

\subsection{Subiektywna ocena stanu zdrowia oraz strategie radzenia sobie ze stresem w zależności od sytuacji zawodowej i płci badanych}

Kolejnym etapem analizy było sprawdzenie, czy sytuacja zawodowa (emerytura bądź kontynuowanie pracy zawodowej), płeć, a także występująca między nimi interakcja stanowią źródło zmienności subiektywnej oceny stanu zdrowia. Ze względu na różnice wieku oraz poziomu dochodów między grupą emerytów a grupą osób pracujących uwzględniono te dwa czynniki jako zakłócające. Przeprowadzono dwuczynnikową analizę kowariancji z wiekiem i dochodami jako czynnikami zakłócającymi. Dla określenia szczegółowych różnic między wyróżnionymi podgrupami wykonano ocenę efektów prostych. Istotne różnice wykazano w obu wskaźnikach subiektywnej oceny stanu zdrowia.

Zakres objawów somatycznych w zależności od sytuacji zawodowej i płci

\begin{tabular}{|l|c|c|c|c|c|c|}
\hline \multicolumn{1}{|c|}{ Efekt } & $d f$ efekt & $M S$ efekt & $d f$ błąd & $M S$ błąd & $F$ & $p$ \\
\hline 1 Emerytura/Praca & 1 & 9,357 & 234 & 15,712 & 0,596 & 0,441 \\
\hline 2 Pleć & $\mathbf{1}$ & $\mathbf{1 4 1 , 7 2 2}$ & $\mathbf{2 3 4}$ & $\mathbf{1 5 , 7 1 2}$ & $\mathbf{9 , 0 2 0}$ & $\mathbf{0 , 0 0 3}$ \\
\hline 1x2 (Interakcja) & 1 & 5,317 & 234 & 15,712 & 0,338 & 0,561 \\
\hline
\end{tabular}


Zakres objawów somatycznych u mężczyzn i kobiet, emerytów i pracujących

\begin{tabular}{|l|c|c|c|}
\cline { 2 - 4 } \multicolumn{1}{c|}{} & Emeryci & Pracujący & Efekty proste \\
\hline Mężczyźni & 8,83 & 7,82 & ni \\
\hline Kobiety & 10,47 & 10,00 & ni \\
\hline Efekty proste & $\mathrm{ni}$ & $M<K^{*}$ & - \\
\hline
\end{tabular}

$* p<0,05$.

Tabela 6

Nasilenie objawów somatycznych w zależności od sytuacji zawodowej i płci

\begin{tabular}{|l|c|r|r|r|r|c|}
\hline \multicolumn{1}{|c|}{ Efekt } & $d f$ efekt & $M S$ efekt & $d f$ błąd & $M S$ błąd & $F$ & $p$ \\
\hline 1 Emerytura/praca & 1 & 16,303 & 234 & 391,445 & 0,042 & 0,838 \\
\hline 2 Pleć & $\mathbf{1}$ & $\mathbf{6 ~ 2 9 6 , 6 6 1}$ & $\mathbf{2 3 4}$ & $\mathbf{3 9 1 , 4 4 5}$ & $\mathbf{1 6 , 0 8 6}$ & $\mathbf{0 , 0 0 0}$ \\
\hline 1x2 (Interakcja) & 1 & 125,071 & 234 & 391,445 & 0,320 & 0,572 \\
\hline
\end{tabular}

Tabe 1 a $6 a$

Nasilenie objawów somatycznych u mężczyzn i kobiet, emerytów i pracujących

\begin{tabular}{|l|c|c|c|}
\cline { 2 - 4 } \multicolumn{1}{c|}{} & Emeryci & Pracujący & Efekty proste \\
\hline Mężczyźni & 30,13 & 25,88 & ni \\
\hline Kobiety & 42,23 & 35,98 & ni \\
\hline Efekty proste & $M<K^{* *}$ & $M<K^{*}$ & - \\
\hline
\end{tabular}

$* p<0,05 ; * * p<0,01$.

Przedstawione wyniki dowodza, że sytuacja zawodowa wśród osób badanych nie stanowi źródła zmienności żadnego ze wskaźników subiektywnej oceny stanu zdrowia (tab. 5, 5a, 6, 6a). Osoby, które są na emeryturze, nie różnią się $\mathrm{w}$ tym zakresie od osób w podobnym wieku kontynuujących aktywność zawodową. Istotne znaczenie dla wariancji wyników ma natomiast płeć osób badanych. Kobiety deklarują szerszy zakres oraz większe nasilenie doświadczanych dolegliwości somatycznych niż mężczyźni, przy czym w przypadku nasilenia różnice te są istotne jedynie w grupie osób pracujących.

Analogiczne analizy przeprowadzono w stosunku do stosowanych strategii radzenia sobie ze stresem. Istotne różnice odnotowano jedynie w przypadku czterech strategii: poszukiwania emocjonalnego wsparcia, zwrotu ku religii, koncentracji na emocjach oraz używania alkoholu. W każdym przypadku źródłem zmienności wyników była jedynie płeć osób badanych. 
W tab. 7-10 przedstawiono wyniki analizy kowariancji wymienionych strategii $\mathrm{z}$ wiekiem i dochodami jako czynnikami zakłócającymi w zależności od sytuacji zawodowej i płci.

Poszukiwanie emocjonalnego wsparcia w zależności od sytuacji zawodowej i płci

\begin{tabular}{|l|c|c|c|c|c|c|}
\hline \multicolumn{1}{|c|}{ Efekt } & $d f$ efekt & $M S$ efekt & $d f$ błąd & $M S$ błąd & $F$ & $p$ \\
\hline 1 Emerytura/Praca & 1 & 0,681 & 234 & 7,085 & 0,096 & 0,757 \\
\hline 2 Pleć & $\mathbf{1}$ & $\mathbf{6 0 , 2 4 5}$ & $\mathbf{2 3 4}$ & $\mathbf{7 , 0 8 5}$ & $\mathbf{8 , 5 0 3}$ & $\mathbf{0 , 0 0 4}$ \\
\hline 1x2 (Interakcja) & 1 & 2,606 & 234 & 7,085 & 0,368 & 0,545 \\
\hline
\end{tabular}

T a be 1 a $7 \mathrm{a}$

Poszukiwanie emocjonalnego wsparcia u mężczyzn i kobiet, emerytów i pracujących

\begin{tabular}{|l|c|c|c|}
\hline & Emeryci & Pracujący & Efekty proste \\
\hline Mężczyźni & 9,75 & 9,37 & $\mathrm{ni}$ \\
\hline Kobiety & 10,57 & 10,62 & $\mathrm{ni}$ \\
\hline Efekty proste & $\mathrm{ni}$ & $M<K^{*}$ & - \\
\hline
\end{tabular}

$* p<0,05$.

Zwrot ku religii w zależności od sytuacji zawodowej i płci

\begin{tabular}{|l|c|r|c|c|c|c|}
\hline \multicolumn{1}{|c|}{ Efekt } & $d f$ efekt & $M S$ efekt & $d f$ błąd & $M S$ błąd & $F$ & $p$ \\
\hline 1 Emerytura/Praca & 1 & 26,827 & 234 & 15,068 & 1,780 & 0,183 \\
\hline 2 Płeć & $\mathbf{1}$ & $\mathbf{1 3 6 , 5 6 6}$ & $\mathbf{2 3 4}$ & $\mathbf{1 5 , 0 6 8}$ & $\mathbf{9 , 0 6 3}$ & $\mathbf{0 , 0 0 3}$ \\
\hline 1x2 (Interakcja) & 1 & 7,520 & 234 & 15,068 & 0,499 & 0,481 \\
\hline
\end{tabular}

Ta be la $8 \mathrm{a}$

Zwrot ku religii u mężczyzn i kobiet, emerytów i pracujących

\begin{tabular}{|l|c|c|c|}
\cline { 2 - 4 } \multicolumn{1}{c|}{} & Emeryci & Pracujący & Efekty proste \\
\hline Mężczyźni & 8,68 & 9,15 & ni \\
\hline Kobiety & 10,93 & 10,73 & ni \\
\hline Efekty proste & $M<K^{*}$ & $\mathrm{ni}$ & - \\
\hline
\end{tabular}

$$
* p<0,05 \text {. }
$$


Koncentracja na emocjach w zależności od sytuacji zawodowej i płci

\begin{tabular}{|l|c|c|c|c|c|c|}
\hline \multicolumn{1}{|c|}{ Efekt } & $d f$ efekt & $M S$ efekt & $d f$ błąd & $M S$ błąd & $F$ & $p$ \\
\hline 1 Emerytura/Praca & 1 & 2,660 & 234 & 5,028 & 0,529 & 0,468 \\
\hline 2 Płeć & $\mathbf{1}$ & $\mathbf{4 9 , 9 6 2}$ & $\mathbf{2 3 4}$ & $\mathbf{5 , 0 2 8}$ & $\mathbf{9 , 9 3 7}$ & $\mathbf{0 , 0 0 2}$ \\
\hline 1x2 (Interakcja) & 1 & 0,611 & 234 & 5,028 & 0,122 & 0,728 \\
\hline
\end{tabular}

T a bela $9 \mathrm{a}$

Koncentracja na emocjach u mężczyzn i kobiet, emerytów i pracujących

\begin{tabular}{|l|c|c|c|}
\cline { 2 - 4 } \multicolumn{1}{c|}{} & Emeryci & Pracujący & Efekty proste \\
\hline Mężczyźni & 9,98 & 10,17 & ni \\
\hline Kobiety & 11,05 & 10,97 & ni \\
\hline Efekty proste & $M<K^{*}$ & $M<K$ tend. & - \\
\hline
\end{tabular}

$* p<0,05 ;$ tend. - tendencja statystyczna; $p<0,1$.

Stosowanie używek w zależności od sytuacji zawodowej i płci

\begin{tabular}{|l|c|c|c|c|c|c|}
\hline \multicolumn{1}{|c|}{ Efekt } & $d f$ efekt & $M S$ efekt & $d f$ błąd & $M S$ błąd & $F$ & $p$ \\
\hline 1 Emerytura/Praca & 1 & 3,968 & 234 & 3,961 & 1,002 & 0,318 \\
\hline 2 Płeć & $\mathbf{1}$ & $\mathbf{3 7 , 3 1 8}$ & $\mathbf{2 3 4}$ & $\mathbf{3 , 9 6 1}$ & $\mathbf{9 , 4 2 1}$ & $\mathbf{0 , 0 0 2}$ \\
\hline $1 \times 2$ (Interakcja) & 1 & 0,218 & 234 & 3,961 & 0,055 & 0,815 \\
\hline
\end{tabular}

T a b e la $10 \mathrm{a}$

Stosowanie używek u mężczyzn i kobiet, emerytów i pracujących

\begin{tabular}{|l|c|c|c|}
\hline & Emeryci & Pracujący & Efekty proste \\
\hline Mężczyźni & 5,13 & 5,25 & ni \\
\hline Kobiety & 4,48 & 4,68 & ni \\
\hline Efekty proste & $M>K^{*}$ & $M>K^{*}$ & - \\
\hline
\end{tabular}

$* p<0,05$.

Uzyskane rezultaty dowodzą, że sytuacja zawodowa wśród osób badanych nie stanowi źródła zmienności żadnej ze strategii radzenia sobie ze stresem (tab. 7-10). Osoby, które są na emeryturze, nie różnią się w tym zakresie od osób w podobnym wieku kontynuujących aktywność zawodową. Istotne znaczenie dla wariancji wyników czterech strategii ma natomiast płeć osób badanych. 
Uzyskane rezultaty wskazują, że kobiety istotnie częściej niż mężczyźni stosują strategie skoncentrowane na emocjach (poszukiwanie emocjonalnego wsparcia, zwrot ku religii, koncentracja na emocjach), rzadziej zaś strategię unikową polegającą na stosowaniu używek. Brak istotnych różnic wystąpił w przypadku wszystkich strategii aktywnych, skoncentrowanych na problemie.

\section{Podsumowanie i wnioski}

W literaturze brak jest danych, które jednoznacznie wskazywałyby na bardziej skuteczne strategie radzenia sobie, choć wielu autorów podkreśla pozytywną rolę strategii aktywnych (H e s z e n, S ę k, 2007). Z kolei podejmowanie strategii unikowych oraz skoncentrowanych na emocjach traktowane jest jako mniej efektywne radzenie sobie. Potwierdzaja to rezultaty przeprowadzonego badania, w którym wykazano związki strategii emocjonalnych i unikowych z negatywną oceną stanu zdrowia. Ciekawym wynikiem jest z kolei brak związków między większością strategii aktywnych (np. rozwiązywaniem problemów, planowaniem, ograniczaniem konkurencyjnych działań, poszukiwaniem wsparcia instrumentalnego) a subiektywną oceną stanu zdrowia osób starszych. Strategie te uważane są bowiem za bardziej skuteczne, częściej pozwalają na rozwiązanie problemu, a więc są też częściej korzystne dla zdrowia jednostki (H e s z e n, S ę k, 2007; O g iń s k a-B u li k, 2006).

$\mathrm{Z}$ drugiej jednak strony kierunek zależności między strategiami radzenia sobie a stanem zdrowia może być odwrotny. Zły stan zdrowia osób starszych wymusza, jako stresor o charakterze dhugoterminowym, stosowanie określonych strategii zaradczych (Kossakowska, 2008). Osoby cierpiące na choroby przewlekłe, doświadczające wielu intensywnych dolegliwości somatycznych, mają często poczucie braku kontroli nad swoim zdrowiem. W takich sytuacjach stosowanie strategii aktywnych, skoncentrowanych na problemie staje się trudne, a niekiedy nawet nieosiagalne dla osoby chorej.

Najsilniej z negatywną oceną stanu zdrowia związana jest strategia polegająca na poszukiwaniu w religii źródła emocjonalnego wsparcia, wskazówki, w jaki sposób postrzegać własną sytuację trudną. Osoby, które często stosują tę strategię, deklarują wiele intensywnych dolegliwości somatycznych, co zgodne jest także $\mathrm{z}$ wynikami innych badań (np. Kaflik-Pieróg, Zadworna-Cieślak, 2010; O gińska-Bulik, 2006). Religijne (duchowe) radzenie sobie może spełniać jednak również pozytywną rolę, co jest coraz częściej akcentowane w literaturze (Folkman, Moskowitz, 2004; Heszen-Ni ejodek, 2003; Heszen, Sęk, 2007). Podejmowanie takich zachowań może być próbą nadania swojemu cierpieniu fizycznemu sensu religijnego. Osoby stosujące tę strategię zyskują nadzieję na możliwość poradzenia sobie, czerpią siłę do zmagania się z chorobą, zaczynają w innych kategoriach rozu- 
mieć swoją trudną sytuację. Warto jednak pamiętać, że religijne radzenie sobie może mieć negatywne strony. Dzieje się tak wówczas, gdy religijność staje się jedynym sposobem radzenia sobie z sytuacją choroby, a jednostka nie podejmuje żadnych działań związanych z poszukiwaniem profesjonalnej pomocy medycznej (S a n d e r s o n, 2004).

Subiektywnie odczuwany zły stan zdrowia osób badanych wiąże się także ze stosowaniem strategii polegających na zaprzeczaniu, ignorowaniu faktu zaistniałej sytuacji trudnej, a także wycofywaniu się i rezygnowaniu z podejmowania wysiłków poradzenia sobie. Rezultaty te są zgodne $\mathrm{z}$ cytowanymi w literaturze (np. O g i ń s k a-B u li k, 2006). Takie zachowania mogą świadczyć o tym, że osoby starsze, cierpiące na wiele intensywnych dolegliwości somatycznych, starają się odwrócić uwagę od tego, co trudne i bolesne. Może się to wiązać z przekonaniem, że w tym wieku zły stan zdrowia jest normą i nie można już go polepszyć, a to przekłada się na brak aktywności skierowanej na ulepszenie go.

Wśród strategii pozytywnych istotną rolę dla oceny stanu zdrowia pełni także umiejętność pozytywnego przewartościowania sytuacji trudnej. Osoby stosujące tę strategię potrafią dostrzec w sytuacji trudnej możliwości dla rozwoju osobistego, spostrzec ją w bardziej pozytywnym świetle. Choć strategia ta zaliczana bywa do strategii aktywnych (O g ińska-Bulik, 2006), to jej sens bliski jest radzeniu sobie opartemu na znaczeniu (S. Folkman, J. T. Moskowitz, za: Heszen, Sęk, 2008). Polega ono na nadawaniu znaczenia sytuacjom trudnym i poszukiwaniu w nich sensu. Pozytywne przewartościowanie może być szczególnie cenną strategią w przypadku braku możliwości zmiany sytuacji, która już zaistniała. Osoby starsze częściej niż inni doświadczają spadku swojej wydolności fizycznej i umysłowej, straty wśród najbliższych (śmierć współmałżonka, przyjaciół, rodzeństwa), a także zostają zmuszone do wycofania się z aktywności zawodowej, którą niejednokrotnie chciałyby kontynuować (Finogenow, 2011b). Stosowanie pozytywnej interpretacji wydarzeń trudnych może być wtedy najbardziej efektywną strategią radzenia sobie.

\section{Bibliografia}

$\mathrm{B}$ e e h $\mathrm{r}$ T. A. (1986), The process of retirement: A review and recommendations for future investigations, „Personnel Psychology”, 39, 31-55.

B os sé R., A 1 dwin C. M., Le ven son M. R., Workman-Danie 1 s K. (1991), How stressful is retirement? Findings from the Normative Aging Study, „Journal of Gerontology: Psychological Sciences", 46, P9-P14.

B ry n i e w i c z W. (2007), Pozycja społeczna czlowieka starego, [w:] B. B u g a j s k (red.), Życie w starości, ZAPOL, Szczecin, 225-229.

D u d e k B. (1998), Rozwiqzywanie problemów ze stresem w miejscu pracy. Teoria i zagadnienia praktyczne, Wydawnictwo IMP, Łódź. 
Finogenow M. (2008), Psychologiczne uwarunkowania zadowolenia z życia $w$ wieku emerytalnym - wyniki modelowania równań strukturalnych, „Polskie Forum Psychologiczne", 13 (2), 82-95.

Finogenow M. (2011a), Starzenie się spoleczeństwa $i$ starzenie się kompetencji, [w:] M. Znajmi ecka-Sikora, B. Kędzierska, E. Roszko (red.), Podstawy ksztatcenia ustawicznego od A do Z. Kompetencje pracowników a wspótczesne potrzeby rynku pracy, SATORI druk, Łódź, 211-234.

F in o g e n o w M. (2011b), Zadowolenie z życia w okresie przejścia na emeryture - uwarunkowania socjodemograficzne, [w:] E. B i e l a w s k a-B a t o r o w i c z, L. G o li ń s k a (red.), Rodzina i praca w warunkach kryzysu, Wydawnictwo Uniwersytetu Łódzkiego, Łódź, 335347.

Folkman S., Moskowitz J. (2004), Coping: pitfalls and promise, „Annual Review of Psychology", 55, 754-774.

Frąckiewicz L. (2002), Spoteczne $i$ ekonomiczne konsekwencje procesu starzenia się ludności, [w:] L. F r ą c k i e w i c z (red.), Polska a Europa. Procesy demograficzne u progu XXI wieku, Wydawnictwo Naukowe ŚLĄSK, Katowice, 11-25.

G a 11 T. L., E v a n s D. R., H o w a r d J. (1997), The retirement adjustment process: changes in the well-being of male retirees across time, „Journal of Gerontology: Psychological Sciences", 52B (3), P110-P117.

Golińska L. (2003), Poczucie koherencji a zadowolenie z życia $w$ różnych jego fazach, „Nowiny Psychologiczne”, 4, 33-46.

$\mathrm{H}$ a r d y M. A., Q u a d a g n o J. (1995), Satisfaction with early retirement: making choices in the auto industry, „Journal of Gerontology: Social Sciences”, 50B, S217-S228.

H e s z e n-N i e j o d e k I. (2003), Wymiar duchowy człowieka a zdrowie, [w:] Z. J u c z y ń s k i, N. O g i ń s k a-B uli k (red.), Zasoby osobiste i spoleczne sprzyjajace zdrowiu jednostki, Łódź, Wydawnictwo Uniwersytetu Łódzkiego, 33-47.

H e s z e n I., S ę k H. (2007), Psychologia zdrowia, Wydawnictwo Naukowe PWN, Warszawa.

H e s z e n I., S ę k H. (2008), Zdrowie i stres, [w:] J. S tre la u, D. D o li ń s k i (red.), Psychologia - podręcznik akademicki, GWP, Gdańsk, 681-734.

J u c z yński Z., O g ińs k a-B u lik N. (2009), Narzędzia pomiaru stresu i radzenia sobie, Pracownia Testów Psychologicznych PTP, Warszawa.

Kaflik-Pieróg M. (2004), Konsekwencje stresu zawodowego personelu ratownictwa medycznego, ,Zeszyty Naukowe WSHE w Łodzi”, 1, 101-110.

Ka flik-Pieróg M., Z a dw orna-Ciéślak M. (2010), Psychospoleczne determinanty stanu zdrowia personelu ratownictwa medycznego, [w:] M. A. B a s in s k a, A. R a t a j k a (red.), Psychosomatyka. Problemy i kierunki badań, Wydawnictwo Tekst, Bydgoszcz, 229-240.

K o s sakow s k M. (2008), Strategie radzenia sobie z choroba przewlekta $w$ stwardnieniu rozsianym, „Postępy Psychiatrii i Neurologii”, 17 (1), 15-21.

L a n g 1 o is M. W., C r a m e r K. M. (2005), The Relationship between Household Composition and Retirement Stress, „Guidance \& Counseling”, 20 (2), 89-98.

L a z a r u s R. S., F o $1 \mathrm{k} \mathrm{m} \mathrm{a} \mathrm{n} \mathrm{S.} \mathrm{(1984),} \mathrm{Stress,} \mathrm{appraisal} \mathrm{and} \mathrm{coping,} \mathrm{Springer,} \mathrm{New} \mathrm{York.}$

Mojs E., Głow acka M. D., Głow acka-Rębała A. (2007), Człowiek stary wobec przemian technologicznych, [w:] B. B u g a j s k a (red.), Życie w starości, ZAPOL, Szczecin, $327-333$.

Ogińska-Bulik N. (2006), Stres zawodowy w zawodach ustug spolecznych. Źródta, konsekwencje, zapobieganie. Wydawnictwo Difin, Łódź.

P a $1 \mathrm{~m}$ or e E. P. (1986), Trends in the health of the aged, „The Gerontologist”, 26, 298-302. 
P a sik M. (2007a), Aktywność zawodowa a zadowolenie z życia u osób po 55. roku życia, [w:] B. Kromolnicka, B. B ugajska, K. Seredyńska (red.), Pomoc i opieka w starości, ZAPOL, Szczecin, 115-122.

P a s i k M. (2007b), Poczucie koherencji a zadowolenie z życia u kobiet i mężczyzn na emeryturze, „Acta Universitatis Lodziensis”, Folia Psychologica 11, 67-79.

Pinquart M., Schindler I. (2007), Changes of Life Satisfaction in the Transition to Retirement: A Latent-Class Approach, „Psychology and Aging”, 22 (3), 442-455.

S a n d e r s o n C. (2004), Health Psychology, Wiley, New York.

$\mathrm{Seccombe} \mathrm{K.,} \mathrm{Le} \mathrm{e} \mathrm{G.} \mathrm{R.} \mathrm{(1986),} \mathrm{Gender} \mathrm{differences} \mathrm{in} \mathrm{retirement} \mathrm{satisfaction} \mathrm{and} \mathrm{its}$ antecedents, „Research on Aging”, 8, 426-440.

S e mk ó w J. (2007), Starość jako zadania człowieka uwikłanego w kontekst wspótczesności, [w:] B. B u g a j s k a (red.), Życie w starości, ZAPOL, Szczecin, 33-40.

S tr a ś - R o m a n o w k a M. (2000), Późna dorostość. Wiek starzenia się, [w:] B. H a r w a s$\mathrm{N}$ a p i e r a $\nmid$ a, J. T r e m p ał a (red.), Psychologia rozwoju czlowieka, t. 2, Państwowe Wydawnictwo Naukowe, Warszawa, 263-292.

S w a g l e r M. A., J o m e L. R. M. (2005), The effects of personality and acculturation on the adjustment of North American sojourners in Taiwan, „Journal of Counseling Psychology”, $52,527-536$.

Tr a fi ałe k E. (2003), Polska starość w dobie przemian, Wydawnictwo Naukowe ŚLĄSK, Katowice.

W a rd C., Le ong C. H., L ow M. (2004), Personality and sojourner adjustment: An exploration of the Big Five and the cultural fit proposition, „Journal of Cross Cultural Psychology", 3, 137-151.

W u A. S., T a n g C. S., Y a n E. C. (2005), Post-retirement voluntary work and psychological functioning among older Chinese in Hong Kong, „Journal of Cross-Cultural Gerontology”, 20, $27-45$.

\section{Maria Finogenow}

\section{Coping Strategies and Subjective Health in Retirement Age}

The aim of the study was to analyze the relationship between coping strategies and subjective health in retirement age. The research sample consisted of 240 older people, aged 55-70 (retirees and those, who continue working, both sex). Following techniques were used: The COPE Inventory (C. S. Carver, M. F. Scheier, J. K. Weintraub) and The Somatic Symptoms List (L. Cofta).

The results show significant relationships between emotional and escape ways of coping and negative rating of health status. Moreover significant differences in subjective health and coping strategies were found between men and women. Retirees don't differ from employees in subjective health and ways of coping.

Keywords: retirement, subjective health, coping strategies (emerytura, subiektywna ocena stanu zdrowia, strategie radzenia sobie ze stresem). 